Article

\title{
The Cultural Landscape Past of the Eastern Mediterranean: The Border Lord's Gardens and the Common Landscape Tradition of the Arabic and Byzantine Culture
}

\author{
Konstantinos Moraitis \\ School of Architecture, National Technical University of Athens (NTUA), 8A Hadjikosta Str., \\ 11521 Athens, Greece; mor@arsisarc.gr; Tel.: +30-210-6434101
}

Received: 5 January 2018; Accepted: 21 February 2018; Published: 26 February 2018

\begin{abstract}
An evaluation of landscape tradition, in Near and Middle East area, could emphasize a profound past of agricultural experience, as well as of landscape and garden art. In reference to this common past, Byzantine and Arabic landscape and garden art paradigms appear to be geographically and culturally correlated, as proved by a Byzantine 12th century folksong, presenting the construction of a villa, with its surrounding gardens and landscape formations, in the territory of Euphrates River. This song refers to Vasilios Digenes Akritas or 'Border Lord', a legendary hero of mixed Byzantine-Greek and Arab blood; 'Digenes' meaning a person of dual genes, both of Byzantine and Arabic origin, and 'Akritas' an inhabitant of the borderline. At the end of the narration of the song, contemporary reader feels skeptical. Was modern landscape and garden art born in the European continent or was it transferred to Western world through an eastern originated lineage of Byzantine and Arabic provenance?
\end{abstract}

Keywords: Arabic landscape and garden art; Byzantine landscape and garden art; cultural sustainability; political sustainability; Twain-born Border Lord

\section{Introductory References: The Western Interest for Landscape and Its Eastern Precedents}

We ought to remark in advance that the present article is written by a professional design practitioner who believes, however, that space formative practices are not of mere technological importance. They may present, moreover, central cultural assumptions, in many cases correlated to the political identity of the societies in reference, as they not only depict but also support and enforce their political ethics.

It is under the conscious or the unconscious feeling of the political importance, which potentially inhere within landscape and garden art, that Western centralized 'civilization' and afterwards Western extended 'cultural' appreciation ${ }^{1}$ recognized them as emblematic practices. They refer not only to practical interest for space formation, for the reclamation and cultivation of land, for agrarian economy; they also represent an overall volition for the rational control of nature, for its 'mastery and possession'2.

1 We tend to use the term 'civilization' (or the adjective 'civilized') in order to describe societies with centralized organization and centralized production of knowledge, correlated to 'civic' societies principally. In comparison we use the term 'culture' (or the adjective 'cultural') in order to describe a non-necessarily centralized social identity, social behavior and social production in general.

2 As described by René Descartes: 'La science peut nous rendre comme maîtres et possesseurs de la nature - Science may turn us to be masters and possessors of nature' [1] (p. 84). 
We could compare the previous Western need for environmental 'policy', with the expansive colonizing identity of modern Europe, with its political ethics. Thus we could also understand the need of Western historians to present the period of the first Western neoteric political formation, Italian Renaissance, as the natal period of landscape appreciation and landscape art. In contradiction to this approach, cultural geography clearly stated that no society could exist, not possessing landscape formative practices or, at least, a landscape perception for its place of living [2]. This generative affinity between social structure and landscape organizing activity, mental activity of cultural perception and interpretation or applied construction activity, may appear even more 'loudly', in the context of the Eastern Mediterranean and Near and Middle East ${ }^{3}$. We refer to a privileged geo-cultural territory, where the first development of agricultural prosperity coexisted with the first need for geometrical abstraction.

\section{The Eastern Genealogy of the Western Landscape and Garden Art}

We have just presented a central argument of our exposé, insisting on the fact that Western ethnocentrism tends, in many ways, to underestimate the impact of exterior contributions to the genealogy of neoteric Europe. However, it is clear that the input of organized knowledge from Arabic world presented important influences for Europeans, while the same seems to be true for the influences exerted by Byzantine culture as well. It is rather obvious for objective historic research that Byzantine scholars offered an important help to the first flourishing of the Italian Renaissance in Florence. Italian Renaissance could be regarded in this way as the immediate sequence of the Palaiologian Renaissance, a period of important achievements in culture, concerning the revival of ancient Greek wisdom in Byzantine Empire. We could therefore speak of Byzantine originated influences, while at the same time we should remind the imprint of the Arabic knowledge, introduced to Europe through the Iberian Peninsula. An even more detailed description could present a mixed Arabo-Byzantine body of influences as introduced to Europe, for example, through the famous Arabic libraries of Spain, where scriptures of Arab and Greek scholars co-existed.

Let us now return to the exact subject of our interest, the historic past of the landscape perception in the Eastern Mediterranean, in Near and Middle East. Let us now insist on the landscape description in poetry, in folksongs originated in the Middle Byzantine Ages and still in use in Greece and Cyprus. Let us now focus on the rocky landscape backgrounds of the Byzantine icon painting or on the still surviving garden examples of Alhambra. Then we could rather rush to conclude that the geographically extended and prosperous cultures of the past, that of the East Roman Empire, also known as Byzantium, and that of the Arabic kingdoms, could not be alien to landscape and garden art and, moreover, to an important landscape feeling, to an unconscious and in the same time conscious relation to landscape, which was afterwards devaluated by Western neoteric non-reference. We could even assert that a highly developed knowledge of landscape intervention existed in the Byzantine and Arab world, prior for sure to the analogous approaches of the Western Renaissance period; a knowledge that offered its pre-existent maturity to Westerners.

\section{The Political Importance of the Re-Evaluation of the Neoteric Landscape History}

What the present article is all about? Is it about the history of landscape, or is it about the importance of landscape formative techniques in general, of landscape aesthetics or environmental sustainability? We dare to admit that the principal aim of this article tends to surpass the previous issues. Its principal aim is to emphasize the need for cultural and political 'sustainability' of peoples in Eastern Mediterranean, in Near and Middle East; to insist on their need to evaluate their cultural

3 The landscape formative activities described in the Border Lord's folksong that will be presented principally refer to Euphrates region that means to the Middle East zone. However some of its references, as those concerning vegetal acclimatization procedures refer to a larger Eastern Mediterranean and Near East territory, to the extended territory of interconnection between Byzantine and Arab cultural groups. 
and political identity correlated to their profound historic past. Even more, its principal aim has to do with the recognition of their age-long liaisons, of their cross-border bounds mutually correlating their knowledge as well as their tradition and cultural experience. It is under this ultimate political scope that indigenous cultures of Eastern Mediterranean, of Near and Middle East, have to reconsider their correlation to their landscape substratum; not on the 'shallow' prospect of touristic activity only, but on the deepest need for self-conscience and self-esteem.

Western political identity is intensively correlated, since the Renaissance, with landscape perception, with landscape and garden art. The upraising of the organized political control in Italian Florence is clearly expressed through the application of perspective geometry in the re-structure of urbanscape, or in 'extra muros' landscape formations. Baroque grandiose gardens were intimately linked to the promotion of the royal sovereignty in Louis XIV's France or in other European kingdoms. Moreover, the bourgeois innovatory regimes, the innovatory liberal political tendencies, as expressed in the British Isles in particular, were expressly correlated to the genesis of the English 'landscape architecture'. It was under those powerful political connotations that landscape perception and landscape art gradually developed their neoteric ideological allure; it was under those powerful political connotations that the genesis of the neoteric landscape perception and landscape art had to be principally and even exclusively European. In his Dissertation on Oriental Gardening, firstly edited in 1773, the English architect Sir William Chambers referred to the influences exerted to the English landscape architecture through Chinese garden examples [3]. The result was an immediate polemic against his commentary; the principal British space formative art that expressed the British political and social ethics, the British political liberal volition, could not be presented as 'imported' from abroad.

Three centuries after Chamber's proposal, ought we to re-write neoteric landscape history? Do we have to re-evaluate it for the profit of the 'peripheral' influences, which, anyway, used to be historically and politically central in the remote pre-Renaissance past?

\section{A 'Border Lord' of Dual Origin and His Landscape Formative Activity}

We have already commented the fact that Western ethnocentrism has in many ways underestimated the impact that Byzantine and Arabic influences exerted on the genealogy of modern Europe. It is probably because of this generalized devaluation that Byzantine landscape and garden culture has been seriously researched by Western scholars only recently ${ }^{4}$. Offering a comparative example we may comment that Marie Louise Gothein, a pioneer landscape historian, dedicated only six and a half pages to the subject of the Byzantine Gardens, in her famous book A History of Garden $A r t$, while presenting the Islamic Gardens in 26 pages, focusing her interest on the Arabic examples [5] (Vol.1. pp. 137-168). In comparison Italian Renaissance and Baroque gardening was presented by her at the length of 484 pages [5] (Vol.1. pp. 205-459, Vol.2. pp. 1-230). However Gothein presented, both Byzantine and Arabic references in a common chapter, under the title 'Byzantine Gardens and the Countries of Islam', probably recognizing that Byzantines and Arabs shared a common 'ground' of cultural expression and, moreover, a common landscape experience concerning the borderline territories asserted by both populations.

The clearest paradigm of such a common Byzantine and Arabic landscape experience is probably offered by a Byzantine 12th century folksong, usually described by the name of its principal protagonist'Digenes Akritas' or 'Digenis Akritis' [6]. It refers to a fictional personality, a legendary Byzantine hero of mixed Byzantine-Cappadocian Greek and Arab blood, named 'Vasilios Digenes Akritas' or, in English translation, 'Twain-born Border Lord'. In a part of the song named by modern scholars with the indicative title "The Home, the Garden and the Tomb" [6] (pp. 63-66), the construction

4 In the fall of 1991 Dumbarton Oaks dedicated a roundtable to the subject 'Gardens and Garden Culture in Byzantium'. It was followed, in 1996, by a Colloquium under the title 'Byzantine Garden culture', which brought together a group of garden historians with scholars who were experts in Byzantine studies. The proceedings of the Colloquium were published by Dumbarton Oaks Research Library [4]. 
of a villa is presented, accompanied with its surrounding gardens and landscape formations in the territory of Euphrates River, with the addition of a bridge over Euphrates and a monumental tomb on the top of it. The reference to this part of the song, in correlation to the double ethnic origin of its protagonist, will be used as the central argument of our article, exemplifying the assertion that organized landscape formative activity, similar to what developed latter in 14th and 15th century in Europe, already existed in Eastern geo-cultural regions, in the territory of Eastern Mediterranean, in Near and Middle East. If historians agree that the folk song was already in extended use during 12th century then, the cultural experience described by it must be even earlier, possibly originating in the 11th century or even earlier in the 10th century. Extending our previous statement, we may remark in addition that this cultural experience appears to be a common production of cultural affinity between different ethnic groups inhabiting the territory, a production of dual origin at least, as Vasilios Digenes Aktitas himself was.

\section{Presenting the Part of the Folksong Described as "The Home, the Garden and the Tomb"}

'Vasilios Digenes Akritas', we have already mentioned it, are the Greek names of the 'Border Lord'. 'Vasilios' is the first name of the hero to whom the folksong refers, while 'Digenes' and 'Acritas' describe his identity, his personal origin and his social and military status. The adjective 'Digenes' means a person of dual origin and 'Akritas' an inhabitant of the borderline obliged, as it also happened in the previous historic example of the Roman armed 'limitanei' ${ }^{5}$, to react as border guard, in the case of an enemy invasion.

The folksong in question has the form of an extensive epic narration, known under a general title identical, as we have also mentioned, to the name of the hero, 'Digenes Akritas'. Six manuscripts have been preserved dedicated to it, the oldest two held one in Escorial Library, in Spain, in a version of 1867 lines indicated with the letter E, and one in Grottaferrata Library, in Italy, in a version of 3749 lines indicated with the letter G. In the first part of the epic the lives of Digenes' parents are narrated; the way they met, and the way his father, an Arab Emir, was converted to Christianity after abducting and marrying Digenes' mother. Then the Emir resettled in 'Romania', in the lands of the Byzantine population of Greek origin, together with his people. The second part of the song discusses, often from a first-person point of view, Vasilios' acts of heroism on the Byzantine border. Finally, having defeated all his enemies Digenes builds, as described in the last part of the song to which we refer in particular, a luxurious villa by the river Euphrates, surrounded by an extended garden and there he peacefully ends his tormented life.

In a clear way this last part of the narration, entitled by the literary commentary with the description 'The Home, the Garden and the Tomb', may be regarded as evidence of an age-deep experience and organizational knowledge, concerning landscape and garden formation practices. It refers to an age-deep experience and knowledge established in Near and Middle East areas by people of mixed origin or by populations being in correlation to mixed cultural impacts. The above, seems to be the first important statement that our article has already emphasized. A second important statement refers to the maturity and complexity of the examined landscape formative example. The folksong presents an organized variety of practices, starting with a site evaluation previous to the beginning of the construction works. Thus it seems to offer a description of practical guidelines, similar to those proposed two centuries later in the Re Agraria, a guide for agricultural and landscape practices written in poetic form by Michelangelo Tanaglia in Renaissance Florence ${ }^{6}$.

In Akritas' folksong a less detailed sequence of works is denoted, however it is described in an organized way. Following the evaluation of the site, land reclamation activities take place.

5 The Roman 'limitanei' as the Byzantine 'akrites', were settlers of the border Roman or Byzantine zones. The central government offered them the ownership of land and, in return, they ought to protect the empire from enemy invasion.

6 As Mariachiara Pozzana's describes, Michelangelo Tanaglia's Re Agraria, was written in poetic form, thus associated to Digeni's folksong presented in our article [7]. (pp. 120-137). 
Afterwards the villa is built and the formation of the gardens follows. Transplantation of vegetal species from other remote countries is testified and also description of minor constructions is offered, as for example those concerning the decorative fountains of the garden. At the end of the song, the contemporary reader feels astonished. Was modern landscape and garden art born in the European continent during Renaissance period, or was it rather transferred to the Western world through an eastern originated lineage, related to the Byzantine and Arabic culture?

\section{The Landscape Formative Activities in Detail; the Decision for the Construction of the Villa and the Practical and Aesthetic Evaluation of the Site}

Let us follow now the presentation of an extended sequence of landscape formative activities, as presented in the previous folksong of Digenis', in the part of the song entitled 'The Home, the Garden and the Tomb' [6] (pp. 63-66). At the beginning of a song, we have a summary of the heroic feats of Digenis', and his decision to build his own house in the meadows.

'... Then the whole Universe frightened by his power was.

Many local chiefs under his control were, And many chiefs of robbers were by Acritas killed, as well as many 'apelates'"

Thus no other concern for military attacks

Or for military defense had he anymore ... V.1615

And as no other concern for nice deeds had he,

He decided a house to have, a house to build in the meadows ...'

And the folksong continues by describing Digenis' effort to locate the proper site for the construction of his house, an effort correlated to the natural properties of the landscape, the irrigation possibilities and the rich flora of the place, but also with the aesthetic qualities, the 'beauty' of the water streams. The natural formation of the site may already be compared to the aesthetic elegance of an artificially 'composed' garden, of a 'paradise'; a term used to describe in Greek, during this period, not only the holy primordial place of the Scriptures, but also the artificial landscape formation, a garden. Thus we may answer to the arguments of the Western scholars, as for example to the Western centered opinion of Joachim Ritter, according to which the landscape perception has to do with the Function of Aesthetics in the Modern Society, of the Western society in principal [8] (pp. 33-97).

First of all, landscape feeling has not necessarily to do with conscious appreciation and description, or with the conscious 'distance', between the spectator and the objectified evaluated perception of his interest, created in the neoteric world. Otherwise we could not refer any more to a 'phenomenology' of landscape, in the Heidegger's use of the term, or to an immediate aesthetic appreciation of the un-cultivated mind in response to its perception. In any case, even in reference to the sophisticated Western mind of Ritter's exposition, the societies of the Western modernity were not the first to develop a 'res cogitans' examining and evaluating the landscape 'res extensa'. In Digenis' song, the hero visits a sequence of possible sites, where his house, a villa similar to those constructed three or four centuries later in Europe, may be erected accompanied by its surrounding garden. His examination has to do with practical needs and with an aesthetic evaluation as well, many years before the proverbial ascent of the Italian scholar and poet of Renaissance Italy, Francesco Petrarca, on Mont Ventoux [9]. Francesco Petrarca commonly anglicized as Petrarch, is often considered the founder of Humanism, and his landscape wondering from the top of the previous mountain, accompanied by a literary description, is also considered as the first 'civilized' [1] recognition of the landscape aesthetic qualities. In the Border Lord's song we may find descriptions of an analogous aesthetic admiration; though we

7 'Apelates': independent guerilla warriors of the Byzantine border zone. 
refer not to a letter of a prominent scholar, as in the case of Petrarch's but to a folksong, in use by the vast majority of the inhabitants of average or even low education. We refer, however, to the inhabitants in a territory of extremely high cultural past. In comparison to the Western Middle Ages, they still live, at the time that the folksong appears, in a rather active cultural present that lasts until the period of the great destruction created by the European Crusades.

At the beginning of his landscape formative intervention the Border Lord inspects the possible sites of his future installation, finally arriving to the land of Euphrates (Figure 1).

'Thus to the nearby river-bank zone he went,

But no suitable place, for a person as noble as he, he found;

So to the land of Euphrates he decided to go. V.1620

... In a place of meadows many trees he found,

Standing around, thick shadow they offered,

While the beauty of water streams

Down from the mountain was coming. V.1625

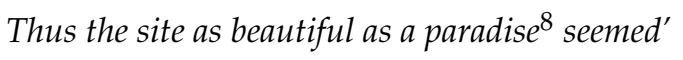

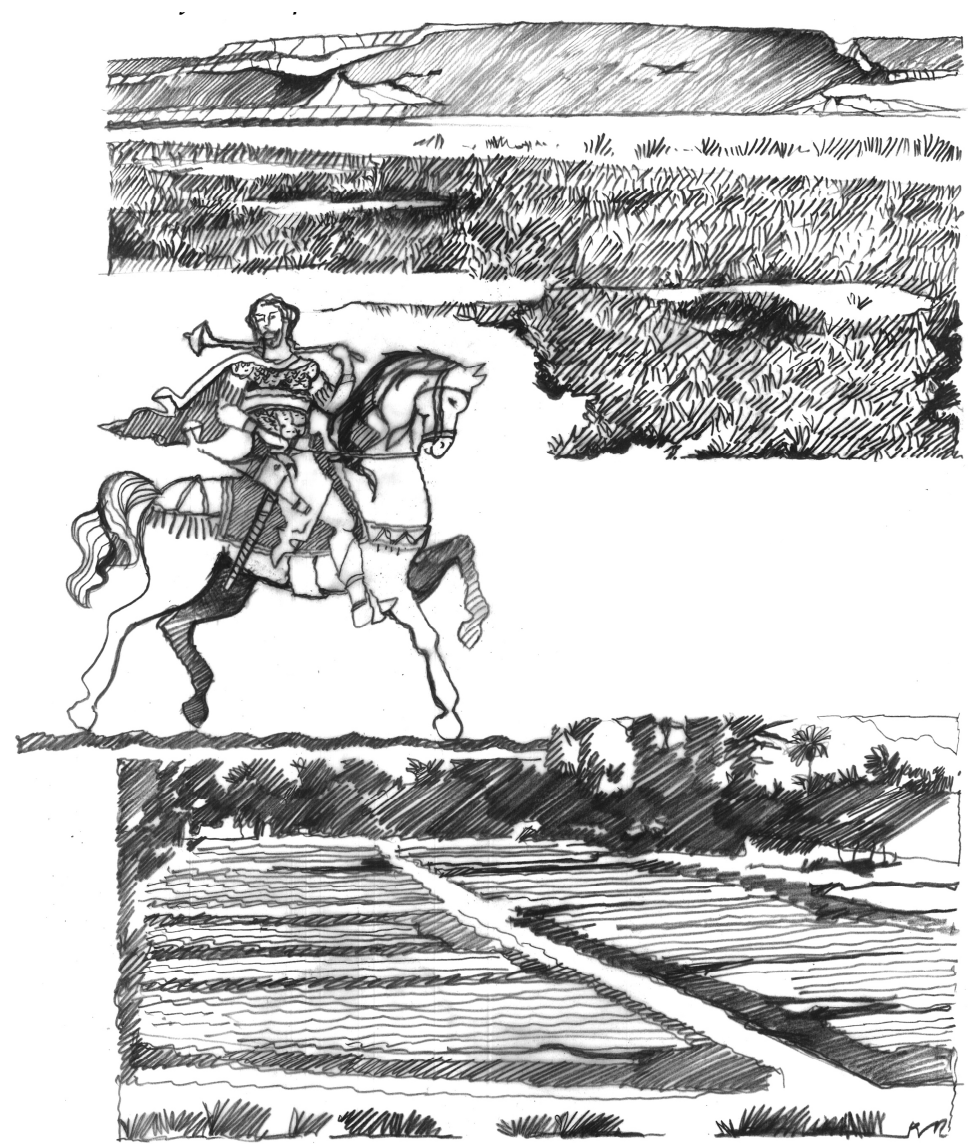

Figure 1. 'Thus to the nearby river-bank zone he went, but no suitable place, for a person as noble as he, he found; so to the land of Euphrates he decided to go ... In a place of meadows many trees he found, standing around, thick shadow they offered' (sketches by the author).

8 The word 'paradise' is used as synonym to the word 'garden'. 


\section{Land Reclamation Activities and Landscape Architecture Interventions}

Then the Border Lord continues with land reclamation activities, as a proof of an already developed experience of similar geotechnical interventions. It would be important to mention that big gardens and landscape architecture interventions, in European history-as in Vaux-le-Vicomte and Versailles Baroque gardens, in Dutch polder formation, or later in the English garden park of Blenheim-were also largely associated to the efficacy of analogous engineering projects; however, the description presented by the Border Lord's song is much earlier.

'So the river out of the meadow sent he,

And a garden of pleasure he actually formed...

... The four confluent-streams of the river he took,

For the irrigation of his whole dominion to use them' V.1635

The description continues with the presentation of the smaller parts of the water management infrastructure, the irrigating fountains (Figure 2, details n. 1 and n. 3) and the 'vivaria', a term describing in the song aquaria constructions, 'full of fishes'.

'Fountains, cast-out of iron he placed,

Enclosed parts to irrigate

(And) vivaria of wonder, full of fishes he made 'V.1638

The landscape formative works continue with an activity rather common to the Western societies during the next centuries. We refer to the acclimatization of vegetal species introduced from distant places, as palm trees and the red St. John's wort, brought from Egypt and described in detail in the song.

'Then palms he planted in this garden V.1641

And out of Egypt the red St. John's wort they brought: V.1640

Its leaves green they are, but its flower red. V.1642

Long its root is, of fragrant wood,

And perfume full its fruits are,

Its branches red, spinning leaves around. V.1645

Snow-white juice out of the root springs out,

Rose-water smell, a sweet euphoria producing'

\section{The Transition from Tradition Cultural Practices to Organized Knowledge: Landscape, Botany, Literary Expression}

Let us quote a recent scientific article concerning the last verse of the song.

It indicates that 'studies have supported the efficacy of St. John's wort as a treatment for depression in humans' [10], an indication close to the descriptive words 'sweet euphoria', used in the song (Figure 2, detail n. 2). We must not be astonished for the medical knowledge of the East Mediterranean remote past historic societies. Byzantines and Arabs were excellent doctors and possessed deep knowledge of medical herbs. Thus we may find 13th century Arabic translations of De Materia Medica, a famous five-volume encyclopedia written much earlier under the ancient

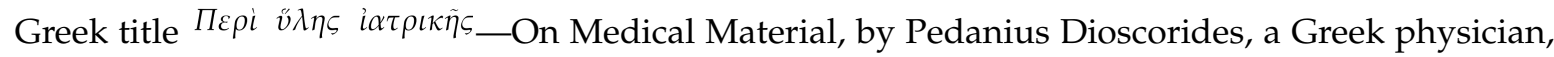
pharmacologist and botanist of the first century A.D. This medical thesaurus was dedicated to herbal medicine and to relate therapeutic treatment, it was widely read for over 15 centuries, and seems to be highly respected by Byzantine and Arab physicians equally. A Byzantine manuscript of it with 
notes in Arabic ${ }^{9}$, probably belonging to the library an Arab doctor of the 11th century, proves that knowledge of both languages, Greek and Arabic, was common at the territory we examine and that cultural and scientific exchanges were a continuous fact. It also proves the correlation to nature in a highly organized way, comprising technical capacity as well as scientific intentions, concerning for example developed landscape formative techniques and a fairly developed expertise in botany.

If we should like to extend our remarks about the refinement of the cultural practices, gradually developed form a state of the tradition and the folk-culture to the state of a centralized sophistication, corresponding to a highly elaborated expression, then we must also mention the changes in the composition of the song of Digenes' itself. While the text of Escorial manuscript appears to be closer to the features of the oral origins, the Grottaferrata manuscript is heavily marked by learned reworking. In both cases the manuscripts preserved, indicate the transformation of the immediate verbal 'tradition' to the written and afterwards to a more sophisticate re-evaluation. This cultural transformation from oral tradition to written, and then to elaborated expression, seems to be comparable to the transformation of the traditional agrarian practices to the developed land reclamation and to the landscape intervention, or to the transformation of the traditional use of herbal remedies to organized botanical, medicinal, and medical knowledge.

\section{Art Imitating Nature and the Mechanical Replicas}

If we return to the folksong we present, we shall find Digenes decorating his garden (or should use the word in plural; his gardens), with highly sophisticated devices usually described as 'automata'. Similar mechanisms, as we know, existed in the Abassid palaces in Bagdad as well as in the throne room $^{10}$ of the Byzantine emperor Theophilos, in Constantinople, in 10th century, as the Italian ambassador Liutprand of Cremona testifies ${ }^{11}$ (Figure 2, detail n. 4).

'... All gold and all silver animals he erected,

Lions, leopards and eagles, partridges and fairies,

Springing out of their mouths and wings

Clear water, fragrant and crystal like. V.1655

All these on sublime fountains were placed'

It is normal to conclude that a culture, animating its gardens with mechanical replicas of living creatures springing out water out of their mouths, possessed a rather developed landscape art. In the 17th century, the famous French philosopher René Descartes proposed a Baroque garden fountain, in his book Les Météores [1] (p. 198). It seems to be, in comparison, a construction much simpler than the 'sublime fountains' of Digenes'.

Then the Border Lord continues with the winged inhabitants of the gardens and, having finished with other projects, he proceeds with the construction of a single vault bridge, over the river, with a monumental tomb on the top of it (Figure 2, n. 5). To describe the bridge, the narration uses again an adjective of aesthetic value; it is a 'handsome bridge' connecting the two banks of Euphrates and, at the same time, the earthly existence of the Lord with his future life in the heavenly garden of Paradise, the term being now used in our article with its religious connotation.

'Then golden cages he hanged on the tree branches

Nice parrots in them, chirruping and telling:

9 It exists in the library of the Georgian Monastery of Iviron or Iveron, an Eastern Orthodox monastery in the monastic state of Mount Athos in northern Greece.

10 For the use of wind powered automata in Bagdad see J. W. Meri's description [11].

11 For automata in Byzantium see G. Brett's description [12] (pp. 477, 487) as well as M. L. Gothein's references [6] (Vol. I, p. 141). In any case it seems that an ancient tradition of manufacturing automata is ascending from Greek antiquity and continues to be vivid in Jewish legends, as those concerning King Solomon's throne and in ancient Chinese references. 
'Long live to the lord and to the lady of his desire'...

... And finally a handsome bridge he built, over Euphrates V.1660

A bridge of a single vault.

A court of four entrances was built over the bridge...

... and inside a tomb there was, V.1665

For his own body to be buried'

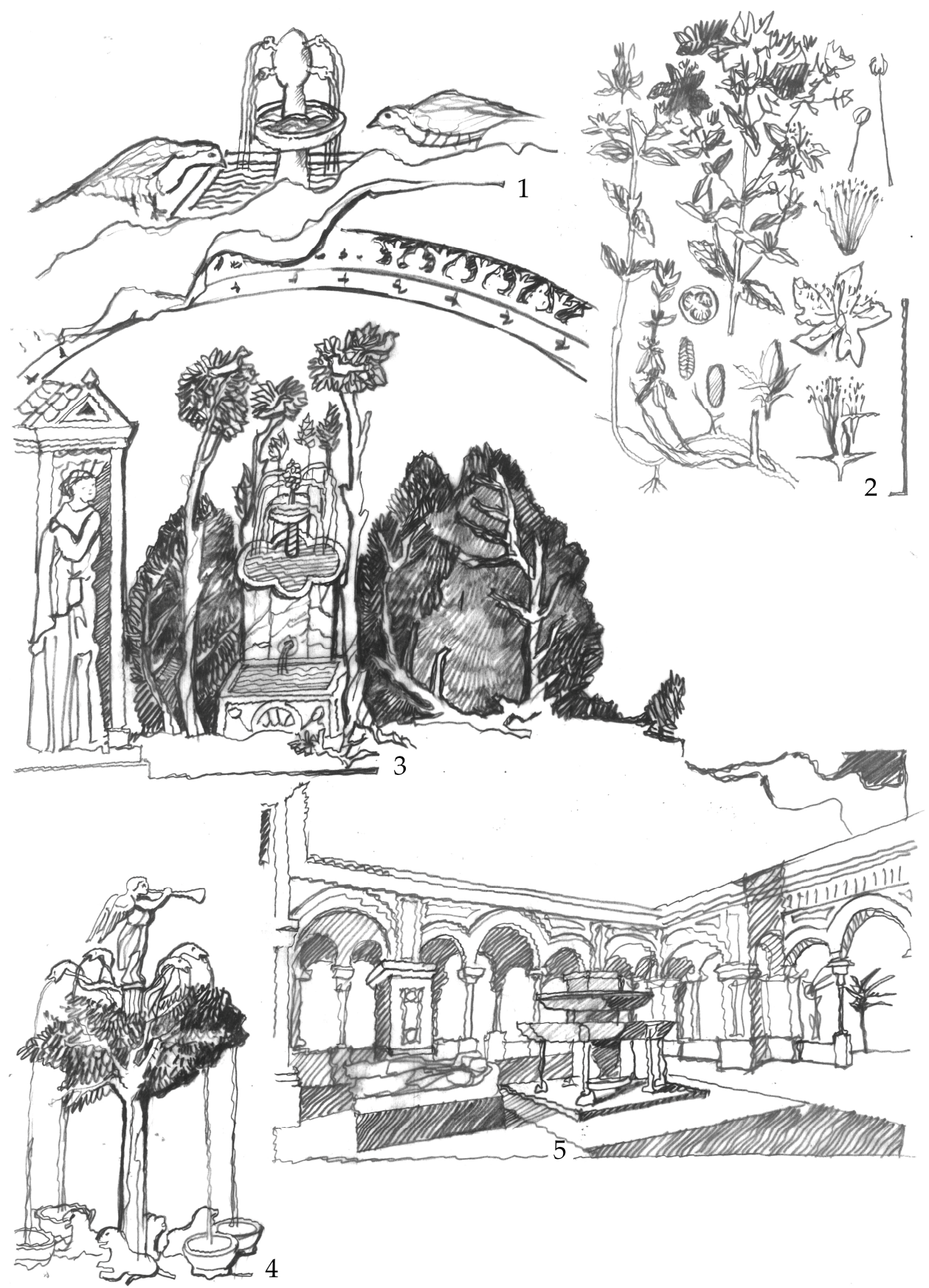

Figure 2. 1 and 3-'Fountains ... enclosed parts to irrigate'; 2-'and out of Egypt the red St. John's wort they brought'; 4- 'lions, leopards and eagles, partridges and fairies springing out of their mouths and wings clear water,'; 5-'a court of four entrances was built over the bridge ... and inside a tomb there was' (sketches by the author). 


\section{Conclusive 'Rhetorical' Questions and Conclusive Statements}

For many Western scholars, the appreciation of landscape must be correlated with Renaissance, more precisely with Petrarch, who climbed on Mount Ventoux in order to enjoy the distant view, in a state of aesthetic delight [9]. In an analogous mode of reference, Western political interpretation of history correlates the emergence of the garden and landscape formative practices with the villas construction in the countryside surrounding Florence, in Toscana; with their landscape 'scenic integration' and their formal gardens.

If we accept this well-known historic approach, how can we then judge the legendary references to the gardens of the Border Lord? What have we to say about the paradigm of the Arabic garden, still preserving its lineage in Alcázar of Seville, in the Court of la Acequi in Generalife, in the Lions Fountain of Alhambra? Finally, how can we judge the need of the ethnic groups, in Eastern Mediterranean, in the Near and Middle East, to establish a contemporary political and cultural 'sustainability', in correlation to their history and to their ancestral landscape of origin?

Comments on the central ideas underlying the present paper, could probably criticize the previous conclusive questions and their tendency to put Eastern and Western evidences of landscape and garden art, into a 'competitive relationship'.

We ought to insist on the importance of this criticism, in order to explain that the previous tendency is not a negative obsession of the author. On the contrary, it seems to express a number of prominent Western intellectuals; Georg Simmel in his essay on the philosophy of landscape, Philosophie der Landschaft [13], Joachim Ritter in his essay on landscape and the function of aesthetics in neoteric society, Landschaft_zur Funktion des Ästhetischen in der Modernen Gesellschaft [8], we already mentioned him, or Ernst Hans Gombrich in his Renaissance Theory of Art and the Rise of Landscape [9]. All of them explicitly insist on the opinion that landscape appreciation is a matter of conscious response towards the qualities of the environment; of conscious response, which could be only produced in neoteric post-Renaissance societies. It is under the same ideological approach that the art historian Kenneth Mackenzie Clark referred to landscape painting, to Landscape into Art [14], insisting on the assumption that it firstly appeared in Renaissance depictions and attained its mature quality during the next centuries.

We could certainly excuse the previous approaches, through the explanation of their limited historical documentation or their restricted theoretical depth. Most likely they were not in touch with the 20th century doctrines of historical geography, of Carl Ortwin Sauer's 'cultural landscape' approaches for example [2]. According to them, no culture could be conceived outside place attributes, without cultural forms superimposed on natural landscape, without conscious or unconscious landscape references. Thus, conscious apperception is not 'sine qua non' causation for cultural landscape formations, while Pre-Renaissance place references and place intervention practices are not necessarily deprived of serious organizational landscape qualities. On the contrary, Arabic garden examples appear to be as formal as the Euclidean geometry gardens of renaissance and Baroque era, correlated to the appraisal of the Western conscious intellect. In an even more specific way, in the folksong just presented, a developed expertise of landscape reclamation techniques is revealed, described side by side to a an equally developed experience of botanic knowledge and flora acclimatization practices, to which we could safely acknowledge the quality of conscious interventions. We could equally reverse Clark's argumentation, by insisting on the arboreal depiction, as presented in the late Paleologean era frescoes in Pantanassa church of Mystras; or we could argue that landscape references on the background of the Byzantine icons are not 'primitive' or 'immature' representations in comparison to the 18th Dutch landscape painting examples. Under a more sophisticated statement of art hermeneutics, they could be accepted as representatives of an expressive 'schematization' much closer to the early 20th century abstract art, than to the 18th and 19th Western realistic tendencies.

However, the most revealing example of the 'competitive relationship' between Western neoteric landscape culture and its oriental precedents is probably the one concerning the public reaction against William Chamber's book, A Dissertation on Oriental Gardening [3], already previously mentioned. 
Chamber's argumentation referred in his book, as we already stated, to the supposition of formative influences exerted to Western landscape art, especially to the 18th British landscape architecture, through examples of Asiatic origin, transferred to the European continent. Though the author's arguments referred to Chinese and not to Near or Middle East influences, the reaction to it was representative of the general desire of the Western societies, to appropriate landscape and garden art and promote them as a genuine Western cultural creation. Minor restricted elements of Arabic, Chinese, or Japanese provenance could be introduced, decorating European gardens with 'arabesque' stylistic elements, or with 'chinoiseries' and 'japaneseries' ornamental constructions; however, principal compositional trends had to be of Western invention. We shall not continue our commentary on this highly irritating subject. We shall only assert that Western landscape theory approaches, as well as Western landscape art hermeneutics, appeared to be cautious towards 'exterior' influences. Landscape art, in both forms of landscape architecture and landscape painting, appeared to be, for four centuries at least, representative of the high level of the Western political identity and everyday social ethics; it seemed thus inconceivable that their attitude, regarded as principally Western, could be produced through alien guidance.

Our primary concern in the essay presented was to prove that mature landscape apperception, as well as mature landscape formation techniques, already existing in the Eastern Mediterranean and Near and Middle East area, at least 400 years earlier than the Renaissance flourishing of the garden art in Tuscany and afterwards to Rome and the rest of Italy. We could of course try to locate even older important paradigms, going backward to Hellenistic and Roman gardens, to Macedonian and Pompeii frescoes. We shall insist however in Eastern Mediterranean and Near and Middle East 10th century, for three interrelated reasons.

The first one refers to the similarity of the Border Lord's folksong description, to an analogous poetic landscape formative guide, written during 14th century in Florence. We already mentioned it; it was Michelangelo Tanaglia's De Re Agraria [7]. However the Border Lord's garden is described in a folksong, and not in a poem written by an intellectual presenting himself as an agriculture and landscape formative techniques specialist. It refers therefore to an extended knowledge, shared not only by educated readers but also by a much larger cultural group of interest, in 10th century Eastern Mediterranean and Near and Middle East; by an extended cultural group that produced this landscape knowledge at least two centuries before the appearance of the folksong describing it.

The second reason refers to the fictional creator of the landscape works described in the song. The Border Lord is a fictional personality; it represents nevertheless the osmosis of two co-existing cultures, the Byzantine and the Arabic one, their shared common experience, their interchanged knowledge and practices. They could even claim, those two interconnecting cultural groups, a common origin, mixed genes, rather bringing them together than separating them. Landscape formation practices could be regarded as closely correlated to this cultural osmosis.

The third reason, justifying the general attitude of the present essay, could be correlated to a contemporary cultural and political statement. The Border Lord or Digenis Akritas, this fictional hero of double origin, may be described as one of the longest living personalities of the Hellenic heroic Pantheon. Until recently, folk songs commemorating his feats were common in the agricultural regions of Greece and Cyprus, and literary references of Greek modernity presented him as a personification of Hellenic ethnic continuity. However, the Border Lord was not of Byzantine origin only; on the contrary he was half Byzantine and half Arab. It could be an interesting occasion to look backward to Middle and Near East past and indicate to the contemporary inhabitants of this controversial geopolitical territory that, besides continuous antagonism, they also share a deep tradition of synergies, of synergies surpassing religious or ethnic differences, of synergies having probably to do with their common affection to their land and landscape substratum.

Conflicts of Interest: The author declares no conflict of interest. 


\section{References}

1. Descartes, R. Discours de la Méthode, suivi D'extraits de la Dioptrique, et des Météores; Garnier Flammarion: Paris, France, 1966.

2. Sauer, C.O. The morphology of landscape. In Foundation Papers in Landscape Ecology; Wiens, J.A., Moss, M.R., Turner, M.G., Mladenoff, D.J., Eds.; Columbia. University Press: New York, NY, USA, 2007.

3. Chambers, W. A Dissertation on Oriental Gardening; Printer to the Royal Academy: London, UK, 1773; Available online: http:/ / books.google.com (accessed on 20 December 2017).

4. Littlewood, A.; Maguire, H.; Wolshke-Bulmahn, J. Byzantine Garden Culture; Dumbarton Oaks Research Library and Collection: Washington, DC, USA, 2002.

5. Gothein, M.L. Geschichte der Gartenkunst; 1904. English Translation by Archer-Hind A history of Garden Art; Hacker: New York, NY, USA, 1979.

6. Aleksiou, S. Vasilios Digenis Acritis and Armouris' Song, Greek ed.; Ermis publ.: Athens, Greece, 1985.

7. Pozzana, M. Agricoltura e orticoltura nella Toscana del Quattrocento. In Giardini Medicei. Giardini di palazzo e di villa nella Firenze del Quattrocento; Luchinat, C.A., Ed.; Federico Motta Editore: Milano, Italy, 2000.

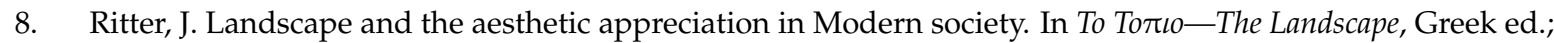
Simmel, G., Ritter, J., Gombrich, E.H., Eds.; Potamos publ.: Athens, Greece, 2004; pp. 33-97, First published as Landschaft_zur Funktion des Ästhetischen in der Modernen Gesellschaft. Aschendorff Verlag: Münster, 1963.

9. Gombrich, E.H. Renaissance Theory of Art and the rise of Landscape. In Norm and Form. Studies in the Art of the Renaissance I; Phaidon Press: London, UK, 1966; pp. 107-121.

10. Klemow, K.M.; Bartlow, A.; Crawford, J.; Kocher, N.; Shah, J.; Ritsick, M. Chapter 11: Medical Attributes of St. Joh's Wort (Hypericum perforatum). In Herbal Medicine Biomolecular and Clinical Aspects, 2nd ed.; Benzie, I.F.F., Sissi, W.G., Eds.; CRC Press: New York, NY, USA, 2011.

11. Meri, J.W. Medieval Islamic Civilization: An Encyclopedia; Routledge publ.: London, UK, 2005.

12. Brett, G. The Automata in the Byzantine 'Throne of Solomon'. Speculum 1954, 29, 477-487. [CrossRef]

13. Simmel, G. Philosophy of landscape. In To Totı -The Landscape, Greek ed.; Simmel, G., Ritter, J., Gombrich, E.H., Eds.; Potamos publ.: Athens, Greece, 2004; pp. 9-31, First published as 'Philosophie der Landschaft,, in Die Guldenkammer II, Bremen 1913.

14. Clark, M.K. Landscape into Art; Icon Editions: New York, NY, USA, 1979. 